\title{
Chlorophyll, Carotenoids Pigments and Growth of Three Onion Cultivars as Affected by Saline Water Irrigation
}

\author{
M. Moursy Hussein ${ }^{(1) \#}$ and S.Y. El-Faham ${ }^{(2)}$ \\ (1) Water Relations and Irrigation Department, Agriculture Division, National Research \\ Centre, Dokki, Cairo, Egypt; (2) Food Technology Department, Food Technology and \\ Nutrition Division, National Research Center, Dokki, Cairo, Egypt.
}

\begin{abstract}
A POT experiment was conducted in the greenhouse of the National Research Center, Dokki, Cairo, Egypt during winter season of 2014/2015 to evaluate the effect of salt stress from diluted seawater (tap water, 2000, 4000 and 6000ppm) on growth, yield and chemical composition of three onion varieties (Giza 6, Giza 20 and Behary red). Nether top height nor the number of green leaves cleared any significant difference between the used three varieties. Furthermore, the bulb/top ratio or bulb/whole plant ratio of Giza 6 plants exceeded those of Giza 20 or Behary red. Behary red leaves showed the lowest values of Chl. a, Chl. $\mathrm{b}$, total carotenoids and $\mathrm{Chl} . \mathrm{a}+\mathrm{Chl}$. $\mathrm{b}$. However, the highest values of these parameters were detected in the leaves of plants of Giza 20 variety and those for Giza 6 comes in between. Top height decreased but the number of green leaves did not affect by salt stress. However, the top and whole plant dry weight drastically depressed by increase salt concentration in water of irrigation (diluted seawater). Nevertheless, bulb to top ratio and bulb to whole plant ratio (in dry weight basis) increased as the salt level increased in the root media. The results also indicated that salinity promoting the concentration of these pigments and this promotion increased until $4000 \mathrm{ppm}$ salt level and tended to decrease with the highest level used but still more than the control.
\end{abstract}

Keywords: Onion (Alluim cepa L.), Varieties, Salinity, Dry matter, Chlorophyll and carotenoids.

\section{Inroduction}

Onion (Allium cepa L.) is considered among the most important vegetable and food crops in Egypt. It is ranked the third in cultivated areas, after potatoes and tomato and also for production and trade in the world and in Egypt. In spite of the production amounts that covers the national consumption needs, but the demand for exportation nowadays grows continuously. Such as interactions between genotype and environment, epistasis and strong environmental affects make difficult to develope workings to promote salinity tolerance of a number of crops. In addition, to understand studies and the high yielding varieties, optimal cultural practices and its responses to moisture and salt stress would lead to qualitative and quantitative improvements in productivity and quality of bulb and seed (Mangal et al., 1989; Rouamba et al., 2001 and Galdón et at., 2008). Renu \& Rashid (2001) noticed that flax plants exhibited enhancement of shoot bud formation after exposure to salt treatment.
The adverse effect of salinity on growth and yield were detected by several authors such as Badr (2001), Cantrell \& Linderman (2001), Abd El-Baky et al. (2003), Abd El-Aziz et al. (2006), Hussein \& El-Greatly (2007) and Pagter et al. (2009). Striu et al. (1972) and Hose et al. (2001) mentioned that permeability of cell walls of onion plants to solutes and water is deferentially reduced by stresses such as drought, salinity, anoxia, heavy metal or nutrients stress.

Developing varieties able to maintain productivity at low or moderate levels of salt stress by breeding investigations may provide a relatively cost-effective short-term solution to this issue (Bahardwaj et al., 2010). The determination of varieties as sensitive or tolerant be an influential strategy to accomplish the salinity stress. According to the behavior in saline conditions, plants can be classed as glycophytes (salt susceptible) and halophytes (salt tolerant) (Flowers et al., 1977; Maas \& Newman, 1978 and Wang, et al., 2005).

"Corresponding author emails: hussein43us@yahoo.com, mmoursyhus@gmail.com DOI: $10.21608 /$ AGRO.2018.5738.1125

C2018 National Information and Documentation Center (NIDOC) 
Varietals differences were studied by Rouamba et al. (2001), Chen et al. (2001) and Abd El-Baky et al. (2003). Arvin \& Kazemi (2002) reported that Texas and Dessey cultivars produced the highest and lowest SDW, respectively than Dehdrater and PX492 varieties.

Oueslati et al. (2008), Wu \& Kubota (2008), Pagter et al. (2009) and Xue \& Yang (2009) observed the effect of salinity on photosynthetic pigments in leaves of vegetable and fruit crops.

The interaction effect of varietals differences and salt stress were found by Abd El-Baky et al. (2003) and Bekheet et al. (2006).

This study aimed to evaluate the growth and photosynthetic pigments response of different onion varieties to different salt stress induced by irrigation with diluted seawater.

\section{Materials and Methods}

A pot experiment was conducted in the greenhouse of the National Research Centre, Dokki, Cairo, Egypt during winter season of $2014 / 2015$ to evaluate the effect of salt stress using diluted seawater on growth, yield and chemical composition of three onion varieties. The treatments were as follows:

a) Varieties: Behary red, Giza 6 and Giza 20 .

b) Salinity: Irrigation by water contains 2000,4000 and 6000ppm from diluted seawater and tap water (300ppm) as a control.

The experiment included 4 levels of salinity in combination with three varieties, i.e. 12 treatments in 6 replicates. Metallic ten pots $35 \mathrm{~cm}$ in diameter and $50 \mathrm{~cm}$ in depth were used. Every pot contained $30 \mathrm{~kg}$ of air dried clay loam soil. The inner surface of the pots was coated with three layers of bitumen to prevent direct contact between the soil and metal. In this system, $2 \mathrm{~kg}$ of gravel (particles about $2-3 \mathrm{~cm}$ in diameter), so the movement of water from the base upward. Pysical and chemical properties of used soil are presented in Table 1.

Onion (Allium cepa L.) varieties seedlings were transplanted to pots in winter season at Dec, $1^{\text {st }}$. Plants were thinned twice, the $1^{\text {st }}$ days after sowing and the $2^{\text {nd }}$ two weeks later to leave three plants/pot. Calcium super phosphate $\left(16 \% \mathrm{P}_{2} \mathrm{O}_{5}\right)$ and potassium sulfate $\left(48.5 \% \mathrm{k}_{2} \mathrm{O}\right)$ in the rate of 3.0 and $1.50 \mathrm{~g} /$ pot were added before sowing. Ammonium sulfate $(20.5 \% \mathrm{~N})$ in the rate of $6.86 \mathrm{~g} /$ pot was added in two equal portions, the first after two weeks of transplanting and the second after two weeks later. Irrigation with diluted seawater in different concentrations were started 21 days tell days after transplanting (one irrigation by salt water and the next was by fresh water, alternatively).

Photosynthetic pigments were determined using the method described by Von Wettstein (1957).

Data collected were subjected to the proper statistical analysis with the methods described by Snedecor \& Cochran (1980).

TABLE 1. Pysical and chemical properties of used soil.

\begin{tabular}{lclc}
\hline Characteristics & \multicolumn{2}{c}{ Characteristics } \\
\hline Particle size distribution & & \multicolumn{2}{c}{ Soluble cations and cations (meq/L) } \\
\hline Sand (\%) & 10.33 & $\mathrm{~K}^{+}$ & 0.5 \\
Silt (\%) & 29.40 & $\mathrm{Na}^{+}$ & 3.2 \\
Clay (\%) & 60.27 & $\mathrm{Ca}^{++}$ & 0.5 \\
Texture & Clay soil & $\mathrm{Mg}^{++}$ & 0.5 \\
$\mathrm{PH}(1: 2.5$ Soil:Water) & 8.25 & $\mathrm{CO}_{3}^{--}$ & - \\
$\mathrm{EC}(1: 5)(\mathrm{dS} / \mathrm{m})$ & 0.44 & $\mathrm{SO}_{4}^{--}$ & 0.6 \\
$\mathrm{CaCO}$ & $(\%)$ & $\mathrm{HCO}_{3}$ & 1.6 \\
$\mathrm{O} . \mathrm{M} .(\%)$ & 2.02 & $\mathrm{Cl}^{-}$ & 2.5 \\
\hline & 1.23 & & Available P (ppm) \\
\hline $\mathrm{N}$ & & $\mathrm{P}$ & 219 \\
\hline
\end{tabular}




\section{Results and Discussion}

\section{Varietals differences}

Growth

Neither top height nor number of green leaves cleared any significant differences between the used three varieties. Dry mass of top, bulb or whole plants showed similar response (Giza 20 or Behary red) (Table 2 and Fig. 1). Several studies were done on evaluation of varietal differences of the vegetable crops (Bonasia et al., 2001 and Abdal \& Suleiman, 2003). Kumar et al. (2008) and Khokhar (2009) related the differences to the genetical variation of cultivars or varieties. Martínez et al. (2000) and Roldán et al. (2008) showed differences in vegetative and dry matter parameters of onion varieties. Moreover, Zaki et al. (2009) under saline water irrigation, in pot experiment evaluated some sweet fennel cultivars. They reported that Zefu fino was the highest vegetative growth expressed as plant height, leaf numbers, fresh and dry weight of leaves, bulbs and total plant as well as green yield compared with Selma and dolce cultivars.

Weight of foliage and bulb weight showed significant differences due to the interaction between the two factors, treatments and plant age. A $\sim 22 \%$ reduction in plant weight, 35 days after transplanting, occurred in treatment in comparison to the onion plants irrigated with the control solution (Sta-Baba et al., 2010)

\section{Chlorophyll and carotenoids (photosynthetic pigments)}

Data presented in Table 3 and Fig. 2 indicated differences among varieties in the study under taken. Bhary red variety showed the lowest values of Chl. a, Chl. b, total carotenoids and Chla + Chl. b. However, the highest values of these parameters were detected in plants of Giza
20 variety and those for Giza 6 came in between. Gang et al. (1992) indicated that various varieties of tartary buck wheat has various amount of chlorophyll content. The chlorophyll content are significantly positive correlated to the biomass and grain yield of a single plant. Agar et al. (1998) investigated the chlorophyll content in twenty different varieties and indicated that generally, Italian varieties showed the highest chlorophyll a content. Although, Ghiandalora had the lowest chlorophyll a content among the Italian varieties, its chlorophyll a content was significantly higher than the varieties from other countries. Turkish and Iranian varieties showed an intermediate chlorophyll a, b and total chlorophyll content whereas Syrian and Greek varieties were found to be the lowest. As a result, it could be concluded that Italian varieties were found to be superior in kernel chlorophyll content compared to Turkish and Iranian varieties.

Chowdhury \& Johri (2003) mentioned that experimental findings showed that the leaves of the Bangla variety showed higher chlorophyll content in comparison to Mitha variety. Chlorophyllase activity was on the other hand higher in Mitha variety in comparison to Bangla variety. Karele (2006), using early varieties ('Donskaja polukarlikovaja' and 'Sirvintas-1') and medium to late wheat varieties ('Otto' and 'Bussard') for studied distribution and content of chlorophyll in different plant parts, found that low content of chlorophyll in leaves of late varieties than that of the early varieties. Khalil (2006) noticed that Giza 32 sesame than Shandawell 3 cultivar revealed higher chlorophyll stability index \% during the two growth stages and growing seasons. Efeoğlu et al. (2009) reported the differences in Chlorophyll (Chl.) (Chl. a, Chl. b, total Chl. (a+b) and carotenoid contents of three maize cultivars.

TABLE 2. Plant growth of different onion varieties.

\begin{tabular}{lccccccc}
\hline Variety & Top height & $\begin{array}{c}\text { Number } \\
\text { of leaves }\end{array}$ & Top & Bulb & $\begin{array}{c}\text { Dry weight (g) } \\
\text { plant }\end{array}$ & $\begin{array}{c}\text { Bulb/top } \\
\text { ratio }\end{array}$ & $\begin{array}{c}\text { Bulb/whole } \\
\text { plant ratio }\end{array}$ \\
\hline Behary red & 68.17 & 6.08 & 6.95 & 8.50 & 15.45 & 1.22 & 0.55 \\
Giza 6 & 64.20 & 6.40 & 6.28 & 11.83 & 18.11 & 0.66 \\
Giza 20 & 67.34 & 5.93 & 9.62 & 9.56 & 19.18 & 0.99 & 0.51 \\
LSD at 5\% & N.S & N.S & N.S & N.S & N.S & -1.58 \\
\hline
\end{tabular}




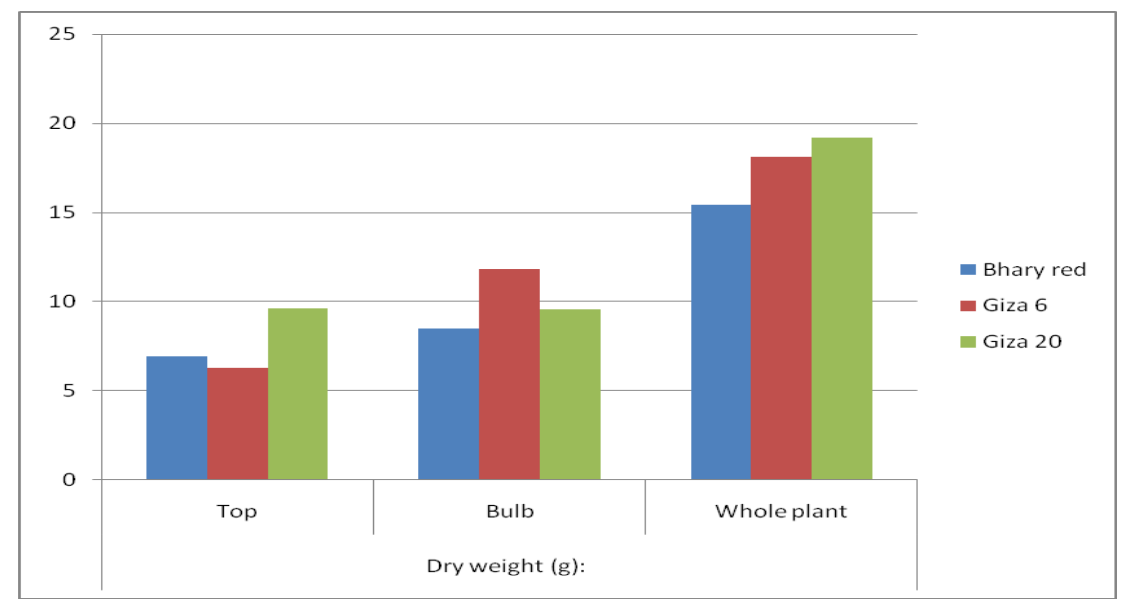

Fig. 1. Plant growth of different onion varieties.

TABLE 3. Photosynthetic pigments (ppm) in plants of some onion varieties.

\begin{tabular}{lcccccc}
\hline Varieties & Chl. a & Chl. b & Carotenoids & Chl. a+Chl. b & Chl. a:Chl. b & Chl. a+Chl. b:Carotenoids \\
\hline Behary red & 5.70 & 3.35 & 0.71 & 9.05 & 1.70 & 12.96 \\
Giza 6 & 6.21 & 4.70 & 0.77 & 10.91 & 1.11 & 14.19 \\
Giza 20 & 6.66 & 5.82 & 0.99 & 12.45 & 1.15 & 12.58 \\
LSD at 5\% & 0.61 & 0.21 & 0.12 & 1.75 & ------- & ------ \\
\hline
\end{tabular}

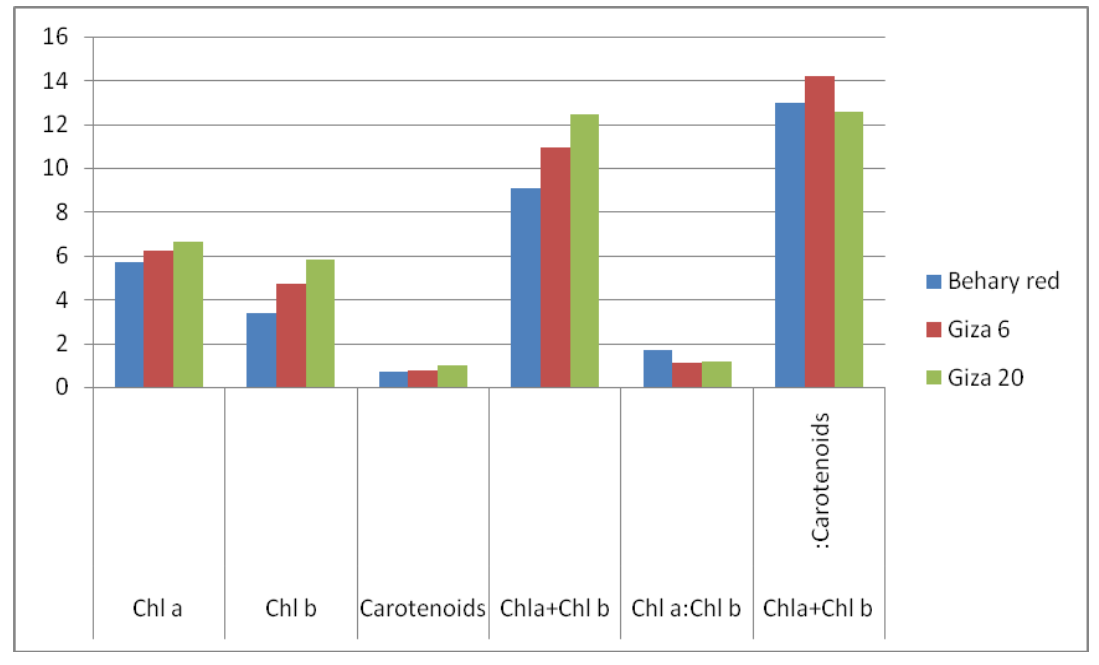

Fig. 2. Photosynthetic pigments in ppm in plants of some onion varieties.

Salinity

Growth

Data presented in Table 4 and Fig. 3 noticed that top height decreased but number of green leaves was not affected by salt stress. However, the dry weight of top and whole plant drastically depressed by the increase in salt concentration in water of irrigation (diluted seawater). Nevertheless, bulb to top ratio and bulb to whole plant ratio increased as the salt level increased in the root media.

Badr (2001) subjected onion or carrot plants to non-saline and saline water irrigation by adding equal parts of $\mathrm{NaCl}$ and $\mathrm{CaCl}_{2}$ to establish 0.25 and $50 \mathrm{mM}$ in 4 days intervals and demonstrated than tops + roots/pot decreased by salinity. Özmen et al (2003) found that much more salts affected 
seedlings establishment and crop yield of onion. Amorim et al. (2002) revealed that garlic plants are relatively tolerant to salinity at the bulb formation stage and initial growth up to 30 days. The salinity treatment started affecting aerial parts during the period 30-60 days after sowing (DAS) while the bulb growth is affected only between 60-90DAS. The most sensitive phase of bulb growth to salinity was the last 30 days of the crop cycle. Al-Hakimi (2000) on broad bean and Cantrell \& Linderman (2001) showed the damages on the growth caused by salinity on lettuce and onion and AlHakimi (2000) and Hamada \&Ahmed (2004) on broad bean and Cantrell \& Linderman (2001) on lettuce and onion, they showed the damages of salinity on growth of these bulbs.

Moreover, Abd El-Baky (2003, 2008) and Mohammed (2002) detected the effect of salinity and antioxidant defense and Abd El-Aziz et al. (2006) detected the effect of salt stress on chemical constituents of the plants. This Findings were confirmed by Arvin
\& Kazemi-Pour (2002) and Rahdari et al. (2012) demonstrated that $\mathrm{NaCl}$ and drought treatments significantly reduced root dry weight (RDW) and stem dry weight (SDW) and increased Na uptake, but reduced $\mathrm{K}$ uptake in shoots and roots and $\mathrm{Ca}$ uptake in roots. Vegetative growth of sweet fennel plants expressed as plant height, leaves number, fresh and dry weight of leaves, bulbs and total plant as well as green yield were depressed linearly by sea water concentrations from 0 up to 5000ppm (Abo El-Magd et al., 2008).

Chlorophyll and carotenoids (photosynthetic pigments)

Table 5 and Fig. 4 showed the data of chlorophylls and carotenoids concentration. These data indicated that salinity promoting the concentration of these pigments and these promotions increased until 400ppm salt level and tended to decrease with the highest level used but still more than the control.

TABLE 4. Plant growth of onion and its response to irrigation with diluted seawater.

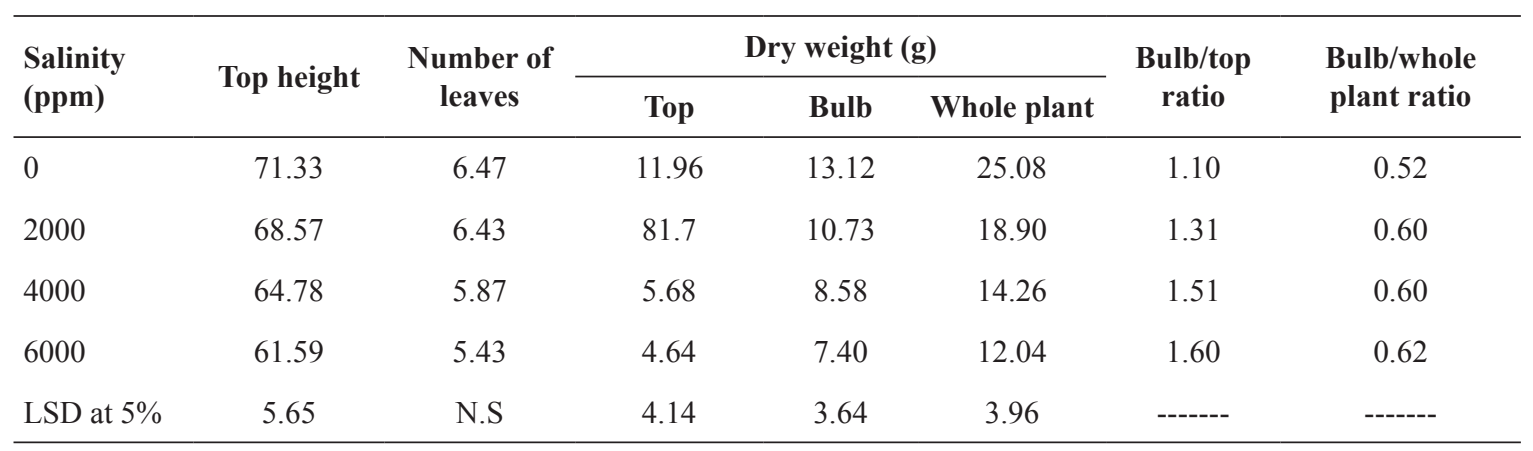

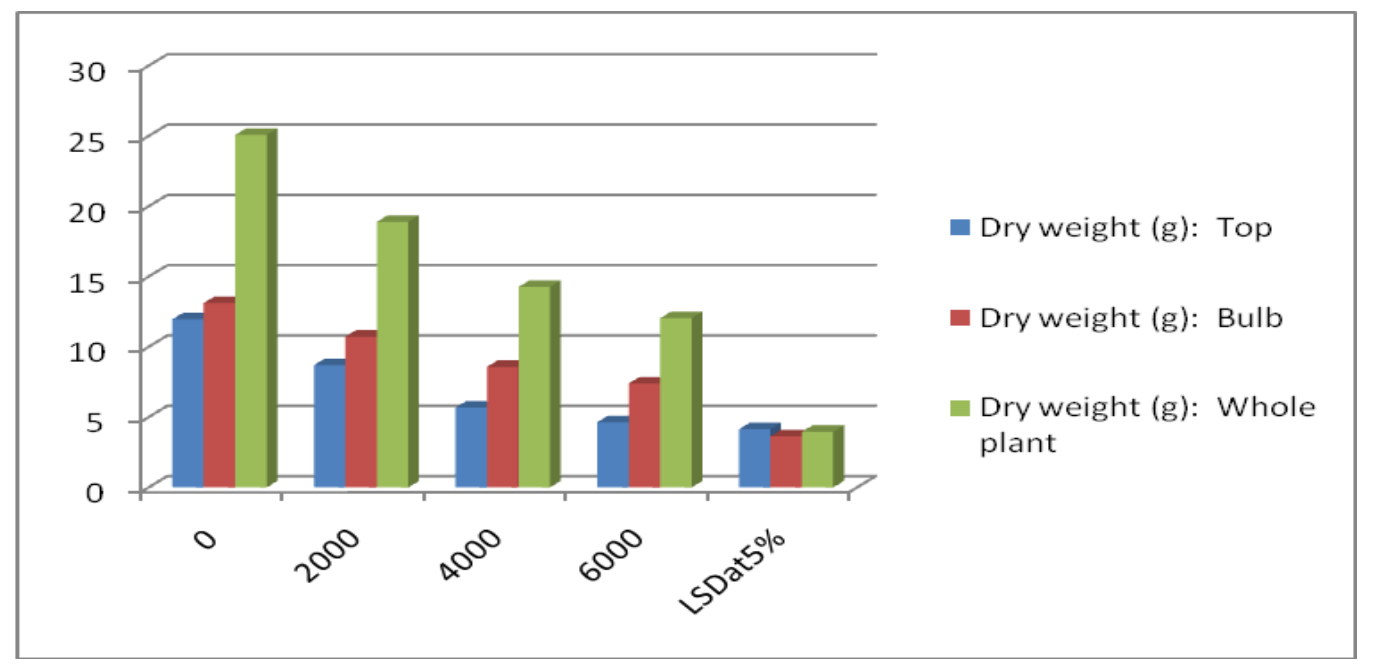

Fig. 3. Plant growth of onion and its response to irrigation with diluted seawater. 
TABLE 5. Effect of salinity on photosynthetic pigments of onion plants.

\begin{tabular}{lcccccc}
\hline Salinity & Chl. a & Chl. b & Carotenoids & Chl. a+Chl. b & Chl. a:Chl. b & Chl. a+Chl. b:Carotenoids \\
\hline Without & 5.95 & 4.19 & 0.79 & 10.14 & 1.43 & 12.84 \\
S1 & 6.22 & 4.61 & 0.75 & 10.83 & 1.35 & 14.44 \\
S2 & 6.39 & $6 ., 37$ & 0.93 & 12.76 & 1.00 & 13.72 \\
S3 & 6.20 & 5.15 & 0.88 & 11.35 & 1.20 & 12.90 \\
LSD at 5\% & N.S & N.S & 0.06 & 0.93 & ----- & ------ \\
\hline
\end{tabular}

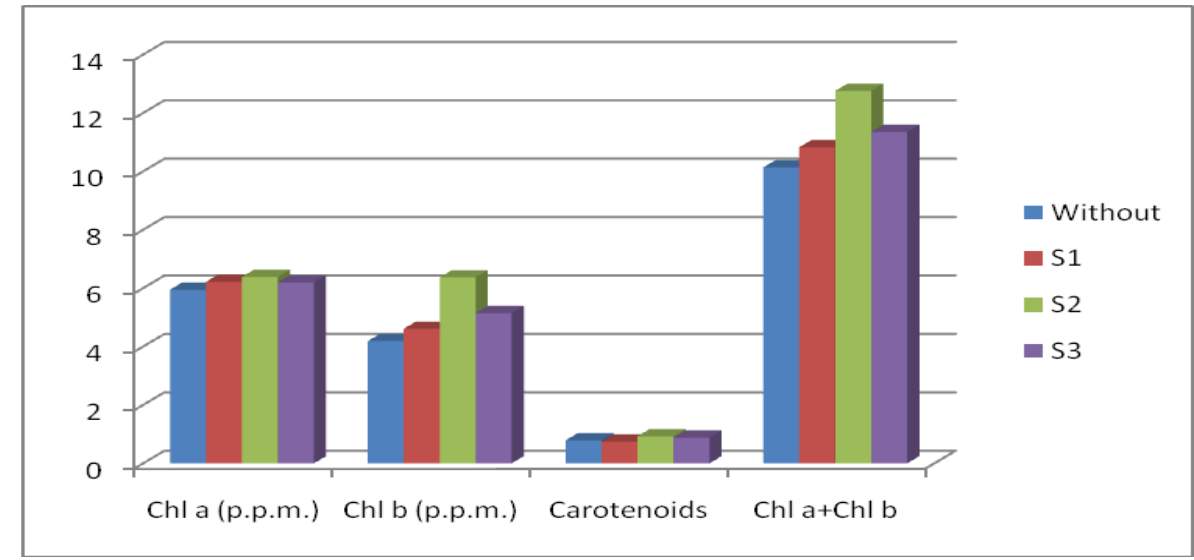

$$
\begin{aligned}
& \text { Tap water } \\
& \mathrm{S} 1=2000 \mathrm{ppm} . \\
& \mathrm{S} 2=4000 \mathrm{ppm} \\
& \mathrm{S} 3=6000 \mathrm{ppm} .
\end{aligned}
$$

Fig. 4. Effect of salinity on photosynthetic pigments in ppm of onion plants.

Due to changes in chlorophyll content and chlorophyll fluoresace, net photosynthesis and stomatal conduction are significantly affected (Agastian et al., 2000 and Doganlar et al., 2010). The reduction of chlorophyll a and chlorophyll $b$ with sodium chloride addition in many crops was attributed to a salt induces of increases in destructive enzymes called chlorophyllase (Rahdari et al., 2012 and Rahdari \& Hossaini, 2011). However, Turan et al. (2007) related these reductions to the weakening of protein-pigments-lipid complex or increase in enzymes activity.

\section{Salinity $X$ variety \\ Growth}

The interaction effect of varietal differences and salinity were illustrated in Table 6 and Fig. 5 , this interaction only significant on top height. The highest effect of high salinity treatment was shown in Giza 6 variety more than Behary red or Giza 20. The differences on the other measured growth characters not enough to reach the level of significant. Nevertheless, bulb to top and bulb/ whole plant weight ratios generally improved by salt stress treatment.
Several studies were done on evaluation the salt tolerant of vegetable crops such as Mingal et al. (1991), Al-Islali \& Bahray (1994), Shannon \& Grieve (1999), Wang \& Nill (2000), Abd El-Baky et al. (2003) and Wang et al. (2005). On onion some studies were conducted to investigate the varietals differences in growth paramaters (Mingal et al., 1991; Al-Islali \& Bahray, 1994 and El-Dewiny et al., 2013).

Hanci \& Cebec (2010) found that "Akgun" determined more tolerant than the other varieties, at $9.6 \mathrm{dSm}^{-1}$ condition. The survived individuals of this variety were selected as "candidate line". At the last year of study, the selected line was evaluated for both seed germination and seedlings growth at three treatment levels of 0 (non stress), $250 \mathrm{mM}$, and $350 \mathrm{mM} \mathrm{NaCl}$ and were compared with the unselected population. Sudha \& Riazunnisa (2015) stated that the results indicated that selections were effective at all two salt-stress levels. Among highest salinity levels, GP, GR and SV were observed in $50 \mathrm{mM}$ and the lowest in $200 \mathrm{mM}$ concentration against control. Agrifound white is the tolerant one and LINE - 28 is susceptible to salt stress. 
TABLE 6. Plant growth of three onion varieties and its response to irrigation with diluted seawater.

\begin{tabular}{|c|c|c|c|c|c|c|c|c|}
\hline \multirow{2}{*}{ Variety } & \multirow{2}{*}{$\begin{array}{c}\text { Salinity } \\
\text { ppm }\end{array}$} & \multirow{2}{*}{ Top height } & \multirow{2}{*}{$\begin{array}{l}\text { Number } \\
\text { of leaves }\end{array}$} & \multicolumn{3}{|c|}{ Dry weight (g) } & \multirow{2}{*}{$\begin{array}{l}\text { Bulb/ } \\
\text { topratio }\end{array}$} & \multirow{2}{*}{$\begin{array}{c}\text { Bulb/ } \\
\text { whole } \\
\text { plant ratio }\end{array}$} \\
\hline & & & & Top & Bulb & Whole plant & & \\
\hline \multirow{4}{*}{$\begin{array}{l}\text { Behary } \\
\text { red }\end{array}$} & 0 & 70.00 & 7.0 & 10.41 & 11.50 & 21.11 & 1.11 & 0.53 \\
\hline & 2000 & 69.33 & 6.0 & 7.20 & 9.98 & 17.18 & 1.39 & 0.58 \\
\hline & 4000 & 70.33 & 5.3 & 5.94 & 7.75 & 13.69 & 1.31 & 0.57 \\
\hline & 6000 & 63.00 & 6.0 & 4.24 & 4.75 & 8.99 & 1.20 & 0.53 \\
\hline \multirow{4}{*}{ Giza 6} & 0 & 72.00 & 6.7 & 9.61 & 15.29 & 24.90 & 1.59 & 0.61 \\
\hline & 2000 & 63.70 & 6.3 & 6.86 & 10.35 & 17.21 & 1.51 & 0.60 \\
\hline & 4000 & 63.33 & 6.3 & 5.09 & 11.13 & 16.22 & 2.19 & 0.69 \\
\hline & 6000 & 57.77 & 5.3 & 3.54 & 10.54 & 14.08 & 2.98 & 0.75 \\
\hline \multirow{4}{*}{ Giza 20} & 0 & 72.00 & 5.7 & 15.87 & 12.57 & 28.44 & 0.79 & 0.44 \\
\hline & 2000 & 72.67 & 7.0 & 10.45 & 11.88 & 22.33 & 1.14 & 0.53 \\
\hline & 4000 & 60.67 & 6.0 & 6.02 & 6.85 & 12.87 & 1.14 & 0.53 \\
\hline & 6000 & 64.00 & 5.0 & 6.13 & 6.92 & 13.05 & 1.13 & 0.53 \\
\hline L.S.D at $5 \%$ & & 7.15 & N.S & N.S & N.S & N.S & ----- & ------- \\
\hline
\end{tabular}

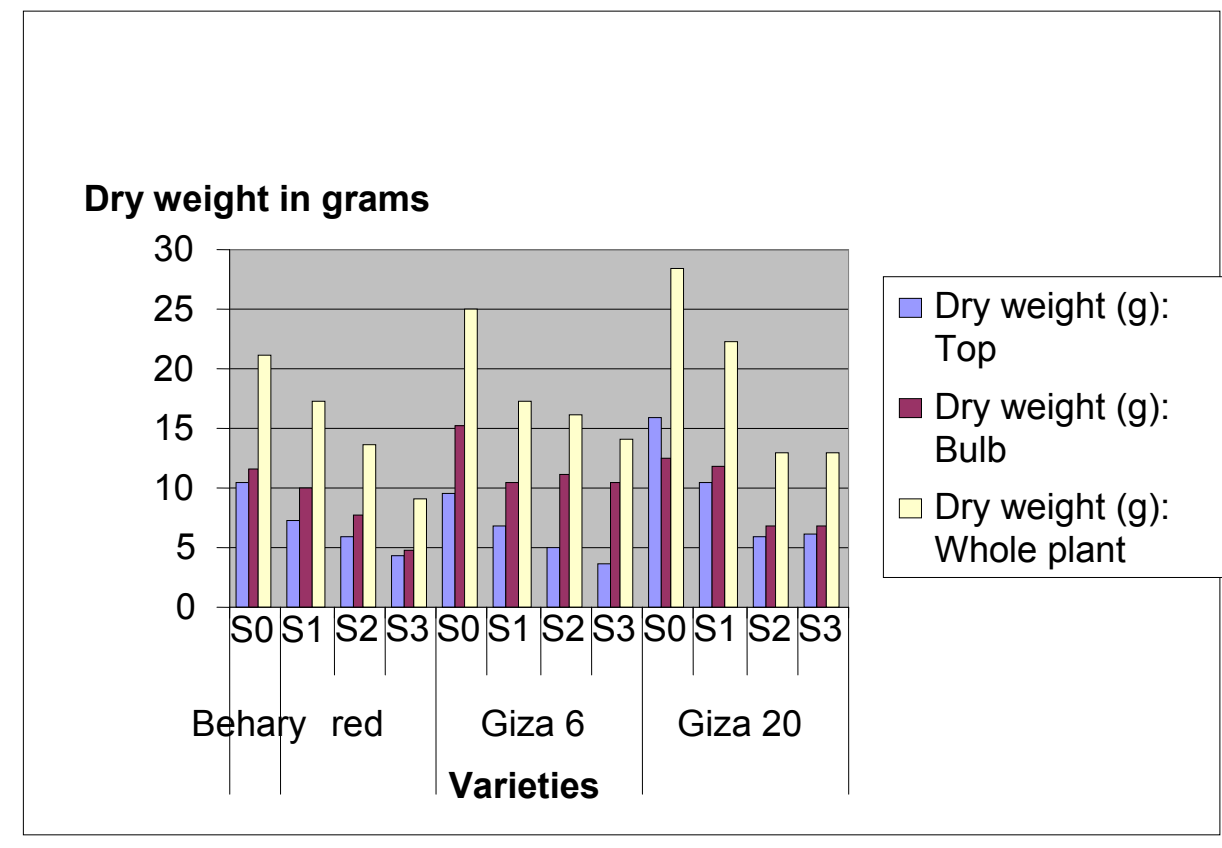

Tap water
$\mathrm{S} 1=2000 \mathrm{ppm}$.
$\mathrm{S} 2=4000 \mathrm{ppm}$
$\mathrm{S} 3=6000 \mathrm{ppm}$.

Fig. 5. Effect of salinity on the dry weight of three onion varieties.

Chlorophyll and carotenoids (photosynthetic pigments)

The interactive effects of varietal differences and salt stress on photosynthetic pigments concentration were presented in Table 7 and Fig. 6.
The highest concentration of Chl. $\mathrm{b}$ in Giza 6 and Bhary red was in leaves of plants irrigated by solution contains $4000 \mathrm{ppm}$ salts, meanwhile, this high concentration in Giza 20 was by the highest level of salt used (6000ppm). The same response was shown in Chl. a+Chl. b concentration in 
Behary red but this parameter in Giza 6 and Giza 20 gave the same response of Giza 20

Greenway \& Munns (1980) explained the salt tolerance mechanisms in nonhalophyte, Efeoğlu et al. (2009) stated that Chl. a, Chl. b, total Chl. (a+b) and carotenoid contents of all maize cultivars were significantly reduced under drought, but a recovery was observed following re-watering. Moreover, Hussein \& El-Dewiny (2011), Hussein et al. (2011a, b and 2012) and Hussein \& Abd El-Hady (2014) recorded the interaction effect of varietal differences and salt or moisture stress chlorophyll and carotenoids content in different crops.

TABLE 7. Effect of salinity on photosynthetic pigments in ppm in plants of some onion varieties.

\begin{tabular}{lccccccc}
\hline Varieties & Salinity & Chl. a & Chl. b & Carotenoids & Chl. a+Chl. b & Chl. a:Chl. b Chl. a+Chl. b:Carotenoids \\
\hline Behary & Without & 5.57 & 2.50 & 0.85 & 8.07 & 2.23 & 9.49 \\
& 2000 & 5.75 & 3.66 & 0.59 & 9.41 & 1.57 & 15.95 \\
& 4000 & 6.34 & 5.12 & 0.70 & 11.46 & 1.24 & 18.37 \\
& 6000 & 5.15 & 4.41 & 0.89 & 9.56 & 1.17 & 10.74 \\
\hline Giza 6 & Without & 6.03 & 4.40 & 0.53 & 10.43 & 1.37 & 19.68 \\
& 2000 & 6.35 & 4.67 & 0.74 & 11.02 & 1.36 & 14.92 \\
& 4000 & 6.02 & 5.02 & 0.98 & 11.04 & 1.20 & 11.27 \\
\hline Giza 20 & 6000 & 6.43 & 4.72 & 0.81 & 11.15 & 1.36 & 13.77 \\
& Without & 6.24 & 5.49 & 0.98 & 11.73 & 1.14 & 11.97 \\
& 2000 & 6.55 & 5.49 & 0.92 & 12.04 & 1.20 & 13.09 \\
& 4000 & 6.82 & 5.96 & 1.12 & 12.78 & 1.14 & 11.41 \\
\hline L.S.D at 5 \% & 6000 & 7.02 & 6.32 & 0.93 & 13.34 & 1.11 & 14.35 \\
\hline
\end{tabular}

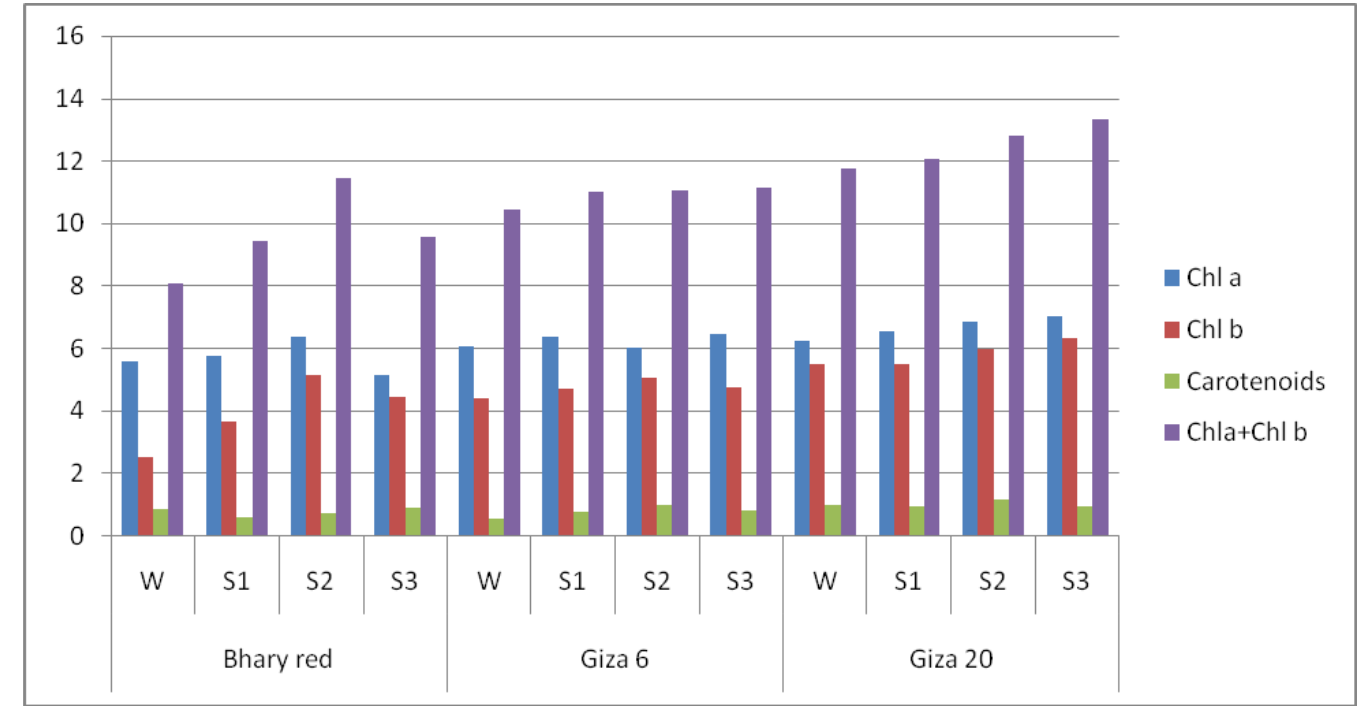

\footnotetext{
$\mathrm{W}=$ Tap water

$\mathrm{S} 1=2000 \mathrm{ppm}$.

$\mathrm{S} 2=4000 \mathrm{ppm}$

$\mathrm{S} 3=6000 \mathrm{ppm}$.
}

Fig. 6. Effect of salinity (ppm) on photosynthetic pigments in plants of some onion varieties. 


\section{Conclusion}

This work conducted to evaluate the effect of salt stress from diluted seawater (tap water, 2000, 4000 and 6000ppm) on growth, yield and chemical composition of three onion varieties (Giza 6, Giza 20 and Behary red). Nether top height nor the number of green leaves cleared any significant difference between the used three varieties. Behary red leaves showed the lowest values of Chl. a, Chl. b, total carotenoids and Chl. $\mathrm{a}+\mathrm{Chl}$. b. However, the highest values of these parameters were detected in the leaves of plants of Giza 20 variety and those for Giza 6 comes in between. Top height decreased but the number of green leaves did not affect by salt stress. However, the top and whole plant dry weight drastically depressed by increase salt concentration in water of irrigation (diluted seawater). The results also indicated that salinity promoting the concentration of these pigments and this promotion increased until 400ppm salt level and tended to decrease with the highest level used but still more than the control. It could be concluded that varieties differently responded to salt stress.

\section{References}

Abdal, M. and Suleiman, M. (2003) Vegetative production in Greenhouse using brackish water. International Symposium on Managing Greenhouse Crops in Saline Environment. Acta Horticulturae, 609, 32 .

Abd El-Aziz, N.G., Mazhar, A.M. and Habba, E. (2006) Effect of foliar spraying with ascorbic acid on growth and chemical constituents of Kaya senegalensis growth under salt condition. American-Eurasion J. Agric. Environm. Sci. 1(3), 207-214.

Abd El-Baky, Hanaa A., Mohamed, Amal A. and Hussein, M.M. (2003) Influence of salinity on lipid peroxidation, antioxidant enzymes and electrophoretic patterns of protein and isoenzymes in leaves of onion cultivars. Assian J. Plant Sci. 2(14-24), 1220-1227.

Abd El-Baky, H.H., Hussein, M.M. and. Baroty, G.S. (2008) Algal extraction improving antioxidants defense, abilities and salt tolerance of wheat plant irrigated with sea water. Electronic Journal of Environmental Agriculture and Food Chemistry, 7(4), 2812-2832.
Abo El-Magd, M.M., Zaki, M.F. and Abo Hussein, S.D. (2008) Effect of organic manure and different levels of saline irrigation water on growth, green yield and chemical content of sweet fennel. Australian J. Basic Applied Sci. 2(1), 90-98.

Agar, L.T., Kafkas, S. and Kaska, N. (1998) Variation in kernel chlorophyll content of different pistachio varieties grown in six countries. ISHS Acta Horticulturae 470: II International Symposium on Pistachios and Almonds.

Agastian, P., Kingsley, S.J. and Vivekanandan, M. (2000) Effect of salinity on photosynthetic and biochemical characteristics in mulberry genotypes. Photosynthetica, 38, 287-290.

Al-Islali, N.Y. and Bahray, A.M. (1994) Growth and organic solutes accumulation in two onion cultivars (Allium cepa L.) stressed with sodium chloride. Alex. J. Agric. Res. 39(3), 597-610.

Al-Hakimi, A.M. (2000) Interactive effects of $\mathrm{Ca}^{++}$ and $\mathrm{NaCl}$ on gas exchange and growth of broad bean (Vicia faba L.). J. Union Arab Biol. Cairo. Physiology \& Algae, 8, 33-43.

Amorim, J.R. De, A., Fernandes, P.D.; Gheyl, H.R and Azevedo, N.C.De. (2002) Effect of irrigation water salinity and its mode of application on garlic growth and production. Pesquisa Agropecuaria Brasileria, 37(2), 167-176.

Arvin, M.J. and Kazemi-Pour, N. (2002) Effects of salinity and drought stresses on growth and chemical and biochemical compositions of 4 onion varieties. J. Sci. Tech. Agric. Natural Resources, 5(4), 41-52.

Badr, M.A. (2001) Plant response to nitrogen and phosphorus under salt stress condition. Al Azhar. $J$. Agric. Res. 34, 291-305.

Bhardwaj, S., Sharma, N., Srivastava, P., Shukla, G. (2010) Salt tolerance assessment in alfalfa (Medicago sativa L.) ecotypes. Botany Research Journal, 3, 1-6.

Bekheet, S.A., Taha, H.S. and Solliman, M.E. (2006) Salt tolerance in tissue culture of onion (Allium cepa L.). Arab J. Biotech. 9(3), 467-476.

Bonasia, A., Elia, A., Gonnella, M. and Santamaria, P. (2001) Substrate reuse, yield and quality of seven 
radish cultivars grown in a closed soilless system. Acta Horticolturae (ISHS), 548, 367-375.

El-Dewiny, Y., Hussein, M.M. and Awad, F. (2013) Influence of mono potassium hosphate fertilizer on mitigate the negative effects of high saline irrigation water on onion Crop. Middle East Journal of Agriculture Research, 3(1), 19-25.

Cantrell, I.C. and Linderman, R.G. (2001) Pre inoculation of lettuce and onion with VA mycorrhyzal fungi reduces deleterious effects of soil salinity. Plant and Soil, 233(2), 269-281.

Chen ShanHu, He Yuxian, Chen QingHe, Chen Junchen, and Jt.Rong Chang (2001) Lighttemperature effect and the main cultivation factors of American onion cultivar Yesgrow. Fujian J. agric. Sci. 16(2), 36-39.

Chowdhury, M.R. and Johri, J.K. (2003) Variations in chlorophyll content and chlorophyllase activity in Bangla and Mitha varieties of Betelvine (Piper betle L.) grown in different soil treatments.Green Pages: Environmental News Sources, 1-3.

Doganlar, Z.B., Demir, K., Basak, H. and Gul, I. (2010) Effects of salt stress on pigment and total soluble protein contents of the three different Tomato cultivars. Afr. J. Agri. 5(15), 2056-2065.

Efeoğlu, B., Ekmekçi, E. and Çiçek, N. (2009) Physiological responses of three maize cultivars to drought stress and recovery. South African Journal of Botany, 75(1), 34-42.

Flowers, T.J, Troke, P.F. and Yeo, A.R. (1977) The mechanism of salt tolerance in halophytes. Annual Review of Plant Physiology, 28, 89-121.

Galdón, B.R., Rodríguez, C.T., Rodríguez, E.R. and Romero, C.D. (2008) Fructans and major compounds in onion cultivars (Allium cepa). Journal of Food Composition and Analysis, In Press, Accepted Manuscript, Available online 22 August 2008.

Gang, Z., Yu, T., Banghua, Y. and Xiaolei, L. (1992) A study on the relationship between the chlorophyll content and the yield of plant of 'Tartary Buckwheat. http://lnmcp.mf.unilj.si/Fago/ SYMPO/1992SympoEach/1992S-122.pdf .

Greenway, H. and Munns, R. (1980) Mechanisms of salt tolerance in nonhaophytes. Annu. Rev. Plant Physiol. 31, 149-190.

Hamada, E.A. and Ahmed, H.E. (2004) Effect of salinity on growth, photosynthetic pigments, carbohydrates and protein contents of two broad bean cultivars. Egypt. J. Physiol. Sci. 25(1), 1-24.

Hanci, F. and Cebec, I. (2010) Improvement of abiotic stress tin onion: Selection studies under salinity conditions. The International Journal of Engineering and Science (IJES), 7(9), 54-58.

Hose, E., Klarkson, D.T., Studle, E., Schreiber, L. and Hartung, W. (2001) The exoderms: A variable apoplastic barrier. J. Exp. Bot. 52(365), 2245- 2264.

Hussein, M.M. and El-Greatly, N.H. (2007) Influences of Alpha-tochopherol and potassium dihydrogen phosphate on growth and endogenous photohormones of onion plants grown under salinity stress. J. Agric. Sci., Mansoura Univ. 32(11), 9741-9151.

Hussein, M.M., Okasha, El.M. and Abdo, M.M. (2011a) Effect of sulphate salinity on growth and photosynthesitic pigments of barley varieties. Res. J. Agric. Biol. Sci. 7(12), 2091-2096.

Hussein, M.M. and El-Diewny, Kamilea Y. (2011b) Mineral constituents of fenugreek varieties grown under water stress condition. Australian Journal of Basic and Applied Sciences, 5(12), 2904-2096.

Hussein, M.M., Abdou, M.A.A. and Soliman, Salwa E. (2012) Growth and photosynthetic pigments of some Egyptian clover varieties as affected by soil moisture depletion. Journal of Applied Sciences Research, 8(7), 34-53.

Hussein, M.M. and Abd El Hady, N.F. (2014) Growth and photosynthetic pigments responses of durum wheat varieties to irrigation by diluted sea water. International Journal of Science and Research (IJSR), 3(12), 1656-1663.

Karele, I. (2006) Chlorophyll content distribution in leaves, stems, and ears in winter wheat. In: "Plant Nutrition", Vol. 92, pp.720-721. Springer Netherlands.

Khalil, S.E. (2006) Physiological studies on sesame plants grown under saline water irrigation conditions. Ph.D Thesis, Fac. Sci., Cairo. Univ., Cairo, Egypt. 
Khokhar, K.M. (2009) Effect of set-size and storage temperature on bolting, bulbing and seed yield in two onion cultivars. Scientia Horticulturae, 122 (2), 187-194.

Kumar, G., Purty, R.S., Sharma, M.P., Singla-Pareek, S.L. and Pareek, A. (2008) Physiological responses among Brassica species under salinity stress show strong correlation with transcript abundance for SOS pathway-related genes. Journal of Plant Physiology, In Press, Corrected Proof, Available online 16 September 2008.

Maas, E.V. and Nieman, R.H. (1978) Physiology of plant tolerance to salinity. In: "Crop Tolerance to Suboptimal Land Conditions", Jung, G.A. (Ed), pp. 277-299. Agron. Soc. America, Crop Sci. Soc. America and Soil Sci. Soc. America, Madison, WI.

Mangal, J.L., Lal, S. and Hooda, P.S. (1989) Salttolerance of onion seed Crop J. Horticulture Sci. 64, 475-477.

Martínez, L.E., Agüero, C.B., López, M.E. and Galmarini, C.L. (2000) Improvement of in vitro gynogenesis induction in onion (Allium cepa L.) using lyamines. Plant Science, 156(2), 221-226.

Mingal, J.L., Sing, R.K. and Yadov, A.C. (1991) Selections for increased salinity in onion seed crop and effect on other characters. Vegetable Sci. 18(2), 140-145.

Mohammed, H.A. (2002) Physiological studies on antioxidative responses and some related metabolites of lupin and sorghum plants grown under sea water. M.SC. Thesis, Fac of Sci., Assuit Univ., Assuit, Egypt.

Oueslati, I., Daoud, D. and Zarrouk, M. (2008) Characterization of virgin olive oil from Super Intensive Spanish and Greek varieties grown in northern Tunisia, Scientia Horticulturae, 120(1), 77-83.

Özmen, A.D., Özdemír, F. and Türkan, I. (2003) Effects of paclobutrazol on response of two barley cultivars to salt stress. Biologia Plantarum, 46(2), 263-268.

Pagter, M., Bragato, C., Malagoli, M. and Brix, H. (2009) Osmotic and ionic effects of $\mathrm{NaCl}$ and $\mathrm{Na}_{2} \mathrm{SO}_{4}$ salinity on Phragmites australis. Aquatic Botany, 90(1), 43-51.
Radhari, P. and Hossaini, S.M. (2011) Salinity stress: A review. Tach. J. Engin. and Appl. Sci. 1(3), 63-68.

Rahdari, P., Tavakoli. S. and Hosseini, S.M. (2012) Studying of salinity stress effect on germination, proline, sugar, protein, lipid and chlorophyll content in Purslane (Portulaca oleraceae L.) leaves. Stress Physio and Bio. J. 8(1), 182-193.

Renu, M. and Rashid, A. (2001) Regeneration of shootbuds on hypocotyls of Linum satitstatum seedlings: A stress-related response. Plant Sci. 161(1), 19-25.

Rouamba, A., Sandmeier, M., Sarr, A. and Ricroch, A. (2001) Allozyme variation within and among population of onion from West Africa. Theor. Appl. Genet. 103, 855-861.

Snedecor, G. and Cochran, W.G. (1990) "Statistical Methods", $8^{\text {th }}$ ed., Iowa State Univ. Press, Iowa USA.

Shannon, M.C. and Grieve, C.M. (1999) Tolerance of vegetable crops to salinity. Scientia Horticulturae, 78, 5-38.

Sta-Baba, R., Hachicha, M., Mansour, M., Hassan Nahdi, H. and Ben Kheder, M. (2010) Response of onion to salinity. The African Journal of Plant Science and Biotechnology, 4(2 Special Issue), 7-12.

Striu, K., Abd El-Fatah, A.M., Abd El-Salam, A. and Abd El-Gawad, M.M. (1972) Salinity effects on the growth of some onion varieties. Bull. Diras. At Inst. 22(1), 167-174.

Sudha, G.S. and Riazunnisa, K. (2015) Effect of salt stress $(\mathrm{NaCl})$ on moephological parameters of onion (Allum cepa L.) seedlings. International Journal of Plant, Animal and Environmental Sciences, 5(4), Oct-Dec-2015.

Turan, M.A., Katkat, V. and Taban, S. (2007) Variations in protein, chlorophyll and mineral elements contents of wheat plants grown under salinity stress. Agron. 6(1), 137-141.

Von Wettstein, D. (1957) Chlorophyll letale and der sub-mikroskopishe formweschselder plastiden. Experimental Cell Research, 12, 427-506. doi:10.1016/0014-4827(57)90165-9

Wang, J. and Nill, N. (2000) Changes in chlorophyll, ribose biphosphate carboxilase - oxygenase, glycine 
betaine content, photosynthesis and respiration in Amaranthesis tricolor leaves during salt stress. J. Hort. Sci. Bioteech. 75, 623-627.

Wang, S.Y., Chen, Q.J., Wang, W.L., Wang, X.C. and Wu, M.Z. (2005) roduction and analysis of transgenic poplar $84 \mathrm{~K}$ with improved salt tolerance by the introduction of OsNHX1 gene. Chin. Sci. Bull. 50, 140-146.

Wu, M. and Kubota, C. (2008) Effects of high electrical conductivity of nutrient solution and its application timing on lycopene, chlorophyll and sugar concentrations of hydroponic tomatoes during ripening. Scientia Horticulturae, 116(2), 122-129.
Xue, L. and Yang, L. (2009) Deriving leaf chlorophyll content of green-leafy vegetables from hyperspectral reflectance. ISPRS Journal of Photogrammetry and Remote Sensing, 64(1), 97-106.

Zaki, M.F., Abo Hussein, S.D., Abo El-Magd, M.M. and El-Abagy, H.M. (2009) Evaluation of some sweet fennel cultivars under saline irrigation water. European J. Sci. Res. 30(1), 67-78.

(Received 18/10/2018; accepted 25/12/2018)

\section{الكلورفيل والكاروتينات ونمو ثلاثة اصناف بصل وتاثرها بالرى بالماء المالح

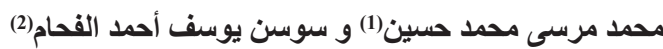

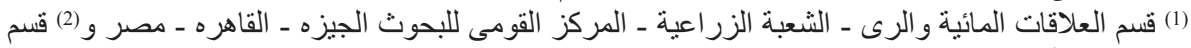 تكنولوجيا الأغذية ـ شعبة الصنات الغذائية والتغذية ـ المركز القومى للبحوث ـ القاهرة ـ ـ مصر.}

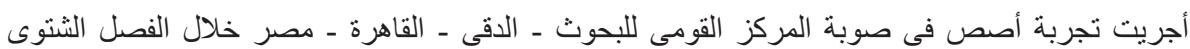

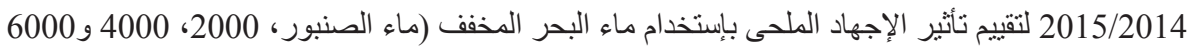

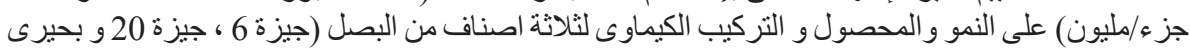

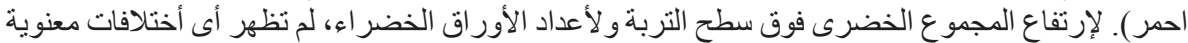

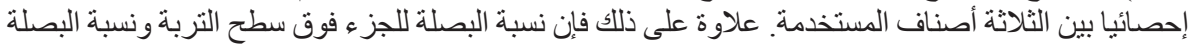

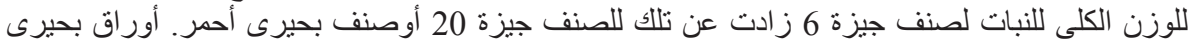

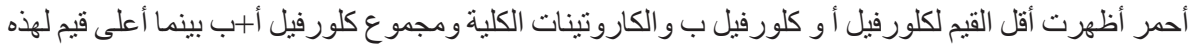

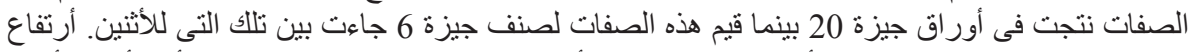

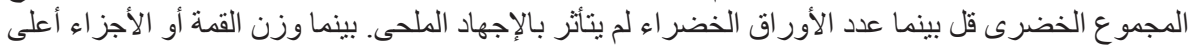

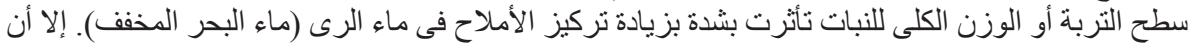

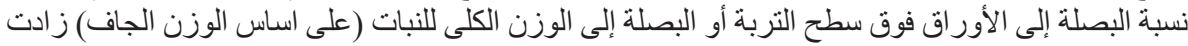

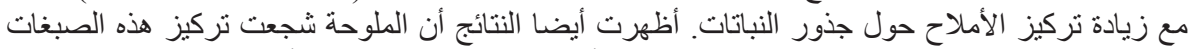

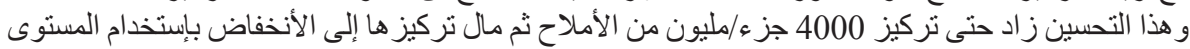

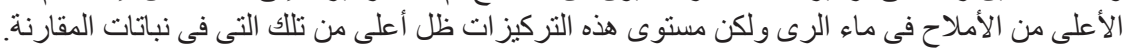

